\title{
Value of Information for Transit Riders
}

\author{
Brendan Nee \\ Graduate Student \\ Department of Civil Engineering \\ University of Minnesota, Twin Cities \\ 500 Pillsbury Drive SE \\ Minneapolis, MN 55455 \\ (612) 626-0024 \\ neex0004@umn.edu \\ Dr. David Levinson \\ Assistant Professor \\ Department of Civil Engineering \\ University of Minnesota, Twin Cities \\ 500 Pillsbury Drive SE \\ Minneapolis, MN 55455 \\ (612) 625-6354 \\ levin031@umn.edu
}

July, 2004 


\begin{abstract}
Transit information systems are crucial for informing riders of their location, destination, and arrival time. After reviewing and classifying the various types of transit information systems, an adaptive stated preference survey was developed and administered to determine the value of information for transit users. The survey consisted of two scenarios which included a picture and a written description. In a series of nine questions, participants were given the choice of a higher fare that included more transit information or a lower fare with less or no information. The average increase in fare for improved transit information was $\$ 0.83$. An OLS model was developed based on the demographic information from respondents. Females, people between the ages of 20 and 30, and those with higher income were willing to pay the most for improved transit information. Respondents who were regular transit users and who lived far from where they worked were willing to pay the least.
\end{abstract}




\section{Introduction}

Transit riders constantly worry about their trip. While using public transportation, passengers are under the control of the transit agency. Delays, route changes, and confusing schedules are just a few of the concerns transit riders have. "After 3 minutes, a passenger waiting for a bus that is not coming expects more information and begins to consider alternatives to fulfill their journey."(US Department of Transportation, 2004) After walking or driving to a transit station that does not have adequate information, passengers do not know if they have just missed the last bus or when the next bus will arrive. This can make the wait time unbearable. When a transit vehicle does arrive, travelers need to verify that it serves the route they wish to take, which can be another place for anxiety. Once on board, passengers must determine when to alight, if any transfers are necessary, and the best walking route to their final destination. All of these factors can make taking transit a stressful experience, especially for the uninitiated.

Transit information problems are magnified for individuals with disabilities. "What may be a surmountable difficulty for the able bodied user may become an impossibility for one who is handicapped.” (Arthur et al., 1992) People with physical or mental disabilities rely heavily on transit. Besides relieving anxiety for new users, transit information is vital for disabled people.

Many of the stresses and worries transit riders experience can be alleviated through information. While the actual transit service does not change - the route and schedule remain the same - the addition of information eases customers' worries, increases their enjoyment and appreciation of transit, and may actually make the trip seem shorter. By increasing the usefulness and pleasantness of transit, riders will be likely to use transit more often. Increased information makes it easier and more 
enjoyable for new riders to negotiate transit and for experienced riders to travel on new routes. Information systems make transit user-friendlier and can eliminate some of the barriers to taking transit.

\section{Types of Information Systems}

There are three locations where it would seem that transit information is desired: pretrip, at transit stops, and in-vehicle. The type of information necessary at each location is different. Table 1 summarizes the types of information systems, the purposes that they fulfill and their usefulness.

\section{Pretrip Information}

Pretrip information can be obtained from printed schedules and maps, a transit agency website, or a telephone information service. Pretrip information focuses on trip planning. This is a critical step for new riders and transit riders who are not familiar with the route. If accurate information cannot be easily obtained, it is not likely that new users will venture onto transit, unless that is their only choice.

\section{Static Pretrip Information}

Printed schedules do not require the use of any equipment or technology, but do require that the user obtain one prior to the trip and understand basic map reading and scheduling. Obviously, printed materials do not contain any real-time information or route planning assistance. Unless a user has schedules for all relevant routes, it is possible that an optimal route exists which is unknown to the user. Another disadvantage of printed schedules is that they can easily become outdated when route and schedule 
changes occur. Often only a few stops are listed and the maps attached are very small. Printed schedules often do not provide what users want: A quick explanation about how to get from point A to point B (Transportation Research Board, 2003).

Automated phone systems that do not provide any real-time information could be considered static in that they are an aural presentation of a printed schedule. These systems can still be useful for users who lack a printed schedule, but they have the same limitations as printed materials.

\section{Dynamic Pretrip Information}

Phones have long been the dominant method of obtaining pretrip information from home. The most effective phone transit information systems provide personal help through live assistance. The advantages to phone information systems are that phones are ubiquitous. This allows phone information systems to be accessed from home as well as en-route using a cellular phone. Also, phone systems offer the potential to interact with a live person, which may be more comforting than a web or printed interface. Customized route information can be obtained and all questions answered with one conversation. This direct inquiry method appeals to many people. In a study done on the London ROUTES call center, four percent of the calls resulted in trips that would otherwise not have used transit (Le Jeune, 1996). In addition, real-time information can be delivered over the phone. The disadvantages to phone information systems are high cost, limited hours, inefficient information retrieval, and limited disability access.

Transit agency websites offer the potential to reach a very large audience with updated information for relatively low cost. Websites offer many advantages to phone or printed information systems. The number of people with internet access and the 
popularity of the internet continue to grow. Websites are available 24 hours a day, offering flexibility to users who want information at any time. Websites are more efficient at distributing information than phone systems. A computer interface is ideal for quickly retrieving, saving, and printing information on routes, policies, and schedules. Phone systems can be awkward, confusing, and time-consuming. Websites also appeal to new users who "just want to look" at transit. While phone systems require that a user have a specific question or route, websites have a self-serve approach that encourages browsing thus making it more likely that a visitor will stumble across a route or service that they didn't know existed. Finally, websites can reach a broad range of people. Computer interfaces provide better accessibility than phone systems to disabled persons (Transportation Research Board, 2002). Visitors and tourists can look up transit information from home.

Websites can offer personalized trip planning. This is perhaps the best aspect of internet-based information systems. Rather than guessing which routes are necessary and then downloading and cross-referencing timetables, users can enter origin and destination pairs and receive routing instructions including transfers and walking information. Transit website trip planners can incorporate multiple modes and transit agencies, adding to their value.

Finally, websites provide the best platform for distributing real-time transit information. A few places have already implemented this on their most popular lines, including Portland, OR. Website visitors can see where transit vehicles currently are and their estimated arrival time for any stop. While this could be done using a phone interface, the computer provides a visual map with much more information readily accessible. Real-time information available online can effectively reduce passenger 
waiting time, the most onerous part of the trip, because an individual can time their departure to arrive just prior to the transit vehicle.

One disadvantage to transit websites is that internet access is not available to everyone. The U.S. Commerce Department published that 50.5 percent of U.S. households have access to internet at home. When considering other internet locations, such as libraries and cafes, the estimate is $64 \%$ (National Telecommunications and Information Administration, 2002). Studies of internet access by transit riders have estimated a low of $28 \%$ in Los Angeles to $80 \%$ for commuter rail in suburban New York (Transportation Research Board, 2002). Internet usage is lower among low-income and older people. Choice riders are more likely to have internet access, and are also likely to be less familiar with the transit system thus making a transit trip planner more useful to them. The number of households with internet access has been steadily increasing and the use of transit websites is also rapidly expanding. Usage data from transit websites through the end of 2001 showed increases of $30 \%$ to $110 \%$ for the previous twelve-month period (Transportation Research Board, 2002).

Because different types of riders obtain information through different sources, it is important to maintain a variety of pretrip planning sources. Frequent riders generally do not need detailed information; they can plan a trip with just the schedule and route map. Younger, more educated and more affluent riders tend to use websites for pretrip information. Also, disabled people rely on websites for transit information (Transportation Research Board, 2002). Robinson et al. (1979) found that females, older persons, and less educated people tended to use a phone information system more often because they liked direct inquiry. Finally, inexperienced riders need to know everything from fares, operating policies, route information and bus stop location (Transportation 
Research Board, 2003). Given the advantages that websites have for distributing information effectively and efficiently, further development of online transit resources will provide users with excellent pretrip planning information.

\section{Transit Stop Information Systems}

Transit stops are where pedestrians interface with transit. Information is crucial at these locations because much of a transit rider's anxiety occurs at these stops while waiting for a vehicle to arrive and determining which vehicle to board. Information provided at transit stops focuses on route-specific information and reliving the anxiety of passengers. Information can be provided statically through posted maps, schedules, route numbers, and station identifiers or dynamically through countdowns, displays, dynamic maps, and verbal announcements.

\section{Static Transit Stop Information}

Static information is an essential part of any transit stop, regardless of size. It answers the questions of "where" and "how". It can also provide a guess as to "when" transit will occur. At the most basic level of static information, some type of identifier needs to be present to denote that a transit stop exists. While a simple "Bus Stop" sign fulfills this requirement, it does not provide any assistance to users nor is it conducive to encouraging new users. The Transit Cooperative Research Program recommends as a minimum that every transit stop should display the route numbers of all vehicles that use that stop, a list of locations served and general operating hours (Transportation Research Board, 1999). Ideally, a basic schedule showing each time that a vehicle will arrive, approximate transit times to all stops, and a map of each route that serves that stop would 
be included as well. This is the basic information required for new riders to negotiate transit from that stop. The only disadvantage of providing static information is that it needs to be updated whenever a schedule or route change occurs. This can be a large expense if each stop must have updated information. However, with good planning and standardized information for each stop along the route, this expense can be minimized.

With this static information, many questions that new riders have would remain unanswered. A system map with operating hours, fare descriptions, and other policies posted at each stop would allow users to plan transfers, seek alternative routes, and become familiar with the basic operational guidelines of the system while waiting for transit. Also, static information sources cannot address the operating issues of transit such as delays, route detours, or other notifications.

On streets near to transit stops, trailblazer signs can be posted to inform and orient people. These signs should include the direction of the transit station, the walking distance from that point and which routes serve it. These signs will help existing passengers locate the bus stop and will also serve as advertisements for transit to nonriders. Areas with high numbers of tourists can benefit greatly from trailblazer signs.

Another set of static information that can be provided at transit stops is oriented to arriving passengers. A map of the area, showing points of interest, walking routes, and other transit routes with transfer information, would be a valuable resource to passengers alighting. This information would not need to be updated as frequently and the information would serve all visitors to the neighborhood, not just transit passengers.

\section{Dynamic Transit Stop Information}


Dynamic information systems at transit stops answer the all-important question of "when". One of the biggest disadvantages to using transit is the uncertainty and anxiety that occurs when waiting for transit vehicles to arrive. Studies have shown that when transit customers are questioned about the duration of their wait time, they cited a time 50\% higher then their actual wait time (Peng et al., 1999). This same phenomenon occurs when a transfer is required. By providing real-time information at transit stops, the worries of passengers can be minimized, greatly enhancing the pleasantness of the trip. Another benefit is the reduced waiting time. If a passenger arrives at a station and notices a long time until arrival, they can spend their time productively at activities near the transit route (Mishalani et al., 2000).

Real-time information systems can affect passenger behavior. If more than one route serves their destination, passengers can make route choice decisions based on the real-time arrival information provided, thereby reducing their total travel time. When notified in advance of a delay, passengers can make important decisions, and avoid the frustrating situation of being late and uninformed. Passengers experiencing delay can switch to another mode, take an alternate transit route, or at least call ahead to notify a waiting party of the delay (Peng et al., 1999) In this way, real-time information systems can make transit more efficient and enjoyable.

One type of useful dynamic system is a display that counts down until the arrival of the next vehicle. This works well at stations served by one or two. Variable message signs and video monitors can be used at transit stations served by many routes. These message signs can show arrival times, and when delays occur they can suggest alternate routes. This simplifies route planning quite a bit. Whereas a static schedule shows an entire day worth of departures that must be sifted through in order to find the information 
desired, a variable message sign streamlines the process by showing only the next few departures and their current status. This is the relevant information at that moment for any transit rider. An announcer can also broadcast this information through a terminal or transit stop. Announcements help the visually impaired; however, announcements cannot often be heard due to background noise or insufficient speakers.

A study of riders in London after the countdown system was initiated showed that a majority of riders felt that waiting time passed more quickly, bus service was more reliable, waiting at night was safer and that passengers' general feelings towards bus travel improved. Of the people surveyed, 93\% thought that the countdown system should be implemented at every bus stop in London (Transportation Research Board, 2003). One hundred percent of riders stated that they use Tri-Met's Transit Tracker always $(82 \%)$ or sometimes $(18 \%)$ and they placed significant value on the information (Transportation Research Board, 2003). The question is not whether real-time information is useful or valued by customers but how to efficiently implement it.

Kiosks at transit stops essentially provide the same services as a transit agency website, but are made publicly available at transit stops. Personalized route planning can be accomplished. Also, many kiosks can provide real-time information on arrivals and delays.

Perhaps the most dynamic of all information sources is live human interaction. Station attendants are an excellent way to provide information to customers. New transit riders especially appreciate the ability to ask their questions in person. In addition, attendants can serve as security monitors to help maintain passenger safety in transit stations. The major disadvantages to attendants are the relatively high labor costs they impose and the fact that they can only serve one customer at a time. However, the 
expense may be justified at busy stations or at stations with lots of new riders, such as airports and passenger rail stations.

\section{In-Vehicle Information Systems}

The final type of information system is in-vehicle. Passengers need to know where to alight and what routes, if any, they are required to transfer to in order to complete their trip. If passengers are traveling through unfamiliar areas and stops are not clearly discernable, a great deal on anxiety can be generated. Passengers fear that they may have missed their stop. In-vehicle information systems can be classified as static and dynamic.

\section{Static In-Vehicle Information}

The simplest way to distribute information in-vehicle is to distribute printed schedules and maps. These can be identical to the format of the pretrip printed pamphlets and the posted transit stop information. While this type of information is better than nothing, it leaves much to be desired. Unless the route map has landmarks on it, it does not help the user figure out where they currently are in relation to their destination. Other forms of static information include route maps and system maps that are posted on transit vehicle walls. This usually works best on rail cars where people are free to move around.

One method to inform the user of their current location is through signage at transit stops. This is prevalent along rail lines where there are fewer stops and each is well defined. By looking out of the windows of a transit vehicle, users can read the name of the stop and compare it on the map to where they want to alight. Signage such as this does not cost very much to implement and is relatively permanent. Clearly labeled 
stations and stops help passengers judge how much longer their trip will be, and reduce passenger anxiety because they know their location at all times.

\section{Dynamic In-Vehicle Information}

When exterior signage at stations and stops is impractical, it is possible to dynamically inform passengers of their location. Variable message boards mounted in transit vehicles and announcements are one way of informing passengers of their location. Alternatively, dynamic lighted maps can be used to indicate location. This has the advantage of including a map with the location so users know where they are relative to their stop. However, this type of system is impractical on a bus due to its configuration.

Cellular phones and other portable devices allow users to access the pretrip information sources en route. This can be useful for finding transfer information and general route information but has limited use in determining present location. This could change with the implementation of low-cost GPS units into handheld communication devices. Also, wireless communication is limited on transit systems that operate underground.

\section{Costs of Information Systems}

Information systems range in price from very low (for posted laminated maps and schedules) to high ( $\$ 10,000$ per info kiosk and over $\$ 300,000$ for website startup costs). Peng et al. (1999) found that transit websites and personal communication devices services were the least expensive to maintain. Once the startup costs of a website are covered, it costs very little to update the information and even less to distribute it. Unlike 
phone centers, there is never a busy signal (except rarely at extremely high peak usage times) and very little labor is required to maintain it. Additionally, websites are easy to implement, are versatile, and have almost unlimited information carrying capacity.

Call centers are cheaper to implement but much more expensive to run than websites. However, until portable wireless internet proliferates, cellular phones represent the only widespread means of mobile communication. For this reason, call centers are still important to maintain. Berlin Transport provides a 24-hour transit information telephone service that receives one million calls annually. The estimated cost per call is $\$ 7.50$ (U.S. Department of Transportation, 2003).

The most effective pretrip information systems combine transit routes from multiple agencies, modes, and carriers into one easy-to-use service. This allows the call center to charge the agency for handling the call. The National Rail Enquiry Service in England provides non-automated transit information to callers. It is funded through charging train operators 0.55 pounds per call. It has been estimated that each call generates 2.45 pounds of revenue for train operators (U.S. Department of Transportation, 2003).

Capital costs for installing automatic vehicle location (AVL) systems varies significantly, but a study of seven US transit agencies found that the cost ranged from \$3000-\$10000 per vehicle while capital costs for real-time information signs (Transportation Research Board, 2003). The annual operations and maintenance cost for AVL systems range from $\$ 100-\$ 700$ per vehicle. These types of systems are relatively new and the costs are likely to decrease as technology improves. Also, because real-time vehicle location systems have been implemented in numerous places already, fewer mistakes will occur in future installations. 
Variable message signs, countdown timers, and other real-time displays are relatively easy to implement. The cost is certainly higher than stationary signs $(\$ 500-\$ 1500$ per unit) but they are versatile, easy to implement, user friendly, and they deal with one of the fundamental problems in transit: anxiety (Peng et al., 1999).

Kiosks are expensive to implement and maintain, but provide personalized service and can be very user friendly. One way kiosks have been partially funded in Madrid is through advertising and co-location rights with the Savings Bank of Madrid ATM machines (U.S. Department of Transportation, 2003). When implemented together, Kiosks and variable message signs provide nearly all the transit information required at a terminal or transit stop.

Variable message signs also are the best option for in-vehicle information systems. Variable message signs and CCTV can partially funded through advertising revenue. Other technologies such as personal communications devices, pagers, and automated announcers are not developed enough to be effectively implemented.

\section{Funding}

Transit information systems can be funded through a variety of sources. Users are willing to pay more for transit service that includes real-time information, ads can be shown on message boards, and increases in transit use can pay for the capital costs and operating expenses of transit information systems.

With many additional variable message signs and CCTVs, ads can very easily be cycled in between transit information. On busier systems, this can translate into a lot of revenue and can likely pay for the cost of the display (but not the AVL). 
Transport for London cites that revenue increased $1.5 \%$ on lines equipped with countdown real-time information systems (Transportation Research Board, 2003). This certainly will help defray the cost of implementation.

Finally, users are willing to pay for information. This can be done either directly through fees (such as a transit phone information system) or through higher fares. Previous studies have found ranges from $\$ 0.01$ to $\$ 0.41$ per trip or up to $\$ 0.50$ per request (Transportation Research Board, 2003).

\section{Benefits of Transit Information Systems}

Improving transit information systems removes one of the largest barriers to riding transit. In a study of California commuters, Abdel-Aty et al. (1996) found that 38 percent of commuters who do not use transit might consider transit if more information were easily available. Because over 80 percent of users surveyed did not currently use transit, this is a significant number of people. This study also found that the information that mattered most to non-transit users was waiting times, frequency of service, and operating hours. Another study from Harris County (METRO) in 1992 found that non-riders primary information need was bus schedules and connection information (Transportation Research Board, 1999). All of these items relate to time, reflecting people's dislike of the uncertain waits and delays associated with transit. Real-time transit information systems can make waiting seem shorter, and in some cases decrease waiting time by allowing passengers to arrive "just in time". A survey by the Puget Sound Regional Council found that agreement with the statement "When waiting, I'm happier if I know when the bus will come" on a scale of -5 to 5 was 3.9 (Transportation Research Board, 2003). This shows that people really value this piece of information. 
Once the barrier of uncertain wait times is removed, customers will be encouraged to use transit more often. A survey by the transit cooperative research program estimated that transit use increased $1 \%$ to $3 \%$ after deploying real-time bus arrival systems (Transportation Research Board, 2003). Data from Europe attributes ridership increases of 5.8\% in Brussels, 5\% in Liverpool, and 3\% in Turin to the implementation of real-time information systems at bus stops (Transportation Research Board, 2003). The primary reason that agencies in this survey chose to implement these systems was to improve the level of customer service. This translates into ridership increases when a significant investment, like a real-time arrival system, is implemented.

Besides luring choice riders, improved transit information systems give disabled riders increased mobility. Information systems help them negotiate transit systems through better pretrip planning and information along the route.

\section{Methodology}

To determine the value of various types of information systems, a stated preference survey was used. This is far easier to collect and control for outside influences than a revealed preference survey and allows for explanation of preferences for scenarios that do not currently exist.

An adaptive stated preference survey was developed using Microsoft Access that was designed to determine that value of nine different types of information systems. In the survey, two scenarios were shown with an associated fare. A description and picture were given of each situation. After choosing one scenario, the fare was adjusted upwards or downwards, depending on the choice until a value was assigned within $\$ 0.125$. This price changing occurred five times per information type. Table 3 shows the choices that 
were presented in the survey. Choice 1 represents the scenario with more transit information and a higher fare. Choice two contains less transit information, but has a constant fare of $\$ 1.00$. Figures 1,2 and 3 show screen shots of each question from the survey. Demographic information was collected using the same MS Access form after the stated preference questions. Also, each participant was required to keep a one day travel diary.

Ninety (90) participants took the survey. These were non-student non-faculty employees of the University of Minnesota that responded to an email and indicated they were interested in participating in the survey. They were paid $\$ 15$ for completing the survey. The survey was administered on four different computers in a computer lab on campus and the stated preference questions dealt with in this paper were the last 9 out of 40 total questions asked.

\section{Results}

The most valuable source of information proved to be systems with real time arrival information. Respondents reported valuing systems $\$ 0.90$ more than systems without. This was followed closely by the real time arrival information system (with no alternative route suggestions). All systems, however, showed that passengers were willing to pay a higher fare.

Table 3 shows the descriptive statistics from the experiment. It can be seen that on average, respondents were willing to pay a higher fare to receive additional transit information, in one case up to $\$ 1.00$ more. 
An OLS regression analysis with various demographics was completed using each of the nine scenarios as a dependent variable. The results are shown in Table 4. The following demographic variables were collected from the MS Access form:

Age

Gender

Dwelling Type

Ownership Status

Education Level

Number of adults in household

Number of children in household

Number of students in household
Vehicles in household

Licensed drivers in household

Household income

Number of days of work per week

Hours of work per week

Telecommuting days per week

Mode used to get to work

Usual Mode

In addition, the travel diaries provided the following data fields:

Distance to work

Travel Time to work

Number of destinations in one day

Total travel time in one day

Mode

A dummy variable was used to place each respondent's age in 10 year cohorts.

The only significant group was the age 20-30 group. A dummy variable was used to denote education level. All survey respondents had a high school diploma and so the only significant variable was a dummy variable for college, either 2 year or 4 year. The number of adults in the household was significant as was the number of licensed drivers. The number of vehicles was significant. Combined household income was broken into three cohorts: high (greater than $\$ 100,000$ annually), medium (between $\$ 40,000$ and $\$ 100,000$ annually) and low (less than $\$ 40,000$ annually). Only high income was a significant variable. A dummy variable was created to show if the respondent had recently used public transit. If the respondent said that they used the bus "usually" or if they used the bus at all on the day of their travel diary, the dummy variable was marked 
as 1. Finally, a dummy variable for a distance from home to work for 20 miles or greater was used.

The model was developed with the dependent variable being the difference in price that a respondent was willing to pay for additional transit information. Since the base price from each of the stated preference trade off questions was $\$ 1$, the dependent variable was simply the price that each respondent was willing to pay minus 1 dollar. After sorting through the variables and to find which ones were significant and removing correlated variables, the following model was developed. The highest level of correlation between variables was 0.342 , between the number of vehicles in a household and the combined household income.

The variables used for the model were:

Dummy variable for Age 20-30

Gender

Number of vehicles in household

Dummy variable for combined household income of over $\$ 100,000$

Dummy variable for transit user

Dummy variable for distance from home to work greater than 20 miles

When age was significant, it had a positive coefficient meaning younger people aged 20-30 are willing to pay more for transit information than older people. Younger people may be more comfortable with new technology and likely demand more from new technologies than older people.

Gender was significant in several scenarios and males were willing to pay less than females for transit information.

The number of vehicles in a household was significant with a positive coefficient. High household income was a significant variable with a positive coefficient. This is 
intuitive because households with more income have more money to spend on transit fares.

The recent bus variable was significant and negative. This shows that regular transit users are not as willing to pay more for additional transit information, probably because they are already familiar with the bus lines they need to use. Certainly, information like maps and trip planner would not help those familiar with transit as much as it would help those who are not regular users. Additional transit information may lure new customers, but existing customers may not be willing to pay an additional amount.

The distance to work variable was significant and negative. This may be because as distance increases, the percentage of the total trip that is wait time diminishes.

\section{Limitations}

A stated preference survey can only capture what respondents say they would do, not what they actually will do if given the choice. This is one major limitation. Also, the results are only as good as the scenarios that were presented. To minimize confusion, a similar picture was used in both scenarios with only one element modified using adobe photoshop.

The sample consisted of University of Minnesota employees. The University of Minnesota is pedestrian friendly and has limited parking. Also, as it is located near downtown Minneapolis, roads can be quite congested during peak times. Finally, it is relatively well served. To determine the value of transit information for commuters who commute from suburb to suburb or other less dense areas, an additional study should be done to include these types of commuters. Also, the effect of stated preference surveys 
may have led those who took this survey to overestimate the amount that they would really be willing to pay for transit information.

The trade off fare with no or less transit information was maintained at $\$ 1.00$. This may be low enough that people were willing to pay extra for additional information. Current transit users in the twin cities pay $\$ 1.25 / \$ 1.75$ for off and on peak respectively. If a higher value was used as the base value, the willingness to pay extra for enhanced transit information systems might diminish.

The survey questions were not randomized and were asked after a series of 31 unrelated questions. This may have biased responses because respondents may have been fatigued or bored by that point. However, because the previous questions were all adaptive stated preference, respondents were used to this type of questioning by the time they got to the transit information section.

\section{Conclusions}

A comprehensive transit information system would include:

- A robust website with route planning that allowed an origin destination pair and departure time to be entered and then returned route results

- Variable message signs with real-time route arrival information at transit stops

- Posted route maps, schedules, and system maps at smaller transit stops

- Kiosks with route planning capabilities at larger transit stops and stations

- Maps of the neighborhood, points of interest, and transfer information at each transit stop

- Variable message signs on transit vehicles with location and transfer information 
This system would fulfill the requests of the commuters from Abdel-Aty's survey (1997) and would be sufficient for mobility impaired.

The people who ride transit the least, the choice riders, are the people that demand the most from transit information systems (Transportation Research Board, 2003). The decision to implement transit information systems needs to be carefully considered on a case-by-case basis. Certainly, not all transit stops can be outfitted with an information kiosk and automated announcers. However, every transit stop should include the most basic information on schedule and route. There are countless people who could conceivably ride transit for at least a few of their trips but choose not to for a variety of reasons. The psychological costs of riding transit preclude many of these riders from using transit. By removing the anxiety barrier and providing information pretrip, at transit stops, and en route, there is one less reason not to ride transit.

In many cases, the potential gains in ridership far outweigh the costs of implementing transit information systems. Technologies for providing real-time information have progressed rapidly and economically feasible solutions are now available. Because much of the technology is very new, it is difficult to compare costs between different systems. However, as more transit agencies implement information systems, components will become standardized, costs will diminish, and problems will decrease.

Perhaps the most promising technology is the real-time countdown display systems that have been implemented in many European, Asian and several US cities. Studies have shown overwhelming positive response to these types of systems and encouragement by users to expand real-time information systems to other routes. Routes that had these types of systems installed witnessed ridership increases of $1 \%$ to $5 \%$ that translated into noticeable revenue increases. Customer satisfaction increased markedly 
and many choice riders stated in surveys that they would be more likely to take transit because of these improvements.

The stated preference survey that was conducted showed that people value transit information. In every scenario, respondents chose a slightly higher fare and a system with more information. The most valuable piece of information, on average, was a route map and schedule. Respondents were willing to pay an additional $\$ 1.00$ per trip for this information. Other valued information systems were real-time arrival systems at transit stations, which respondents would pay between $\$ 0.76$ to $\$ 0.96$ in additional fares for. Other types, such as online information, printed information, and en-route information were valued from $\$ 0.61$ to $\$ 0.95$.

Though goals of transit services vary from place to place, the benefits of increased revenue, increased ridership, and increased rider satisfaction will fulfill the mission statement of any transit service. Most of the real-time information systems are too new to judge the long-term effects, but certainly as technology improves and costs decrease, the use of transit information systems will proliferate. 
Value of Information to Transit Riders

Brendan Nee

\section{Acknowledgements}

Kevin Krizek

Ning Li

Nebiyou Tilahun

$\mathrm{Xi}$ Zou 


\section{References}

Abdel-Aty, Mohamed. "Using Travel Surveys and Experiments to Explore the Potential Impact of Transit Information Systems on Mode Choice." International Symposium on Automotive Technology \& Automation $\left(30^{\text {th }}\right) .1997$.

Abdel-Aty, Mohamed and Jovanis, Paul and Kitamura, Ryuichi. "The Impact of Advanced Transit Information on Commuters' Mode Changing." ITS Journal. Vol. 3(2) pp129-146, 1996.

Arthur, Paul and Passini, Romedi. "Wayfinding: People, Signs, and Architecture." McGraw-Hill: New York, 1992.

Le Jeune, B. “ROUTES: London's Computerised Travel Enquiry System.” International Conference on Public Transport Electronic Systems, 1996.

Mishalani RG; Lee S; McCord MR. "Evaluating Real-Time Bus Arrival Information Systems." Transportation Research Record 1731, pp. 81-87, 2000.

National Telecommunications and Information Administration. "A Nation Online: How Americans Are Expanding Their Use of the Internet." [Online]. Available: http://www.ntia.doc.gov/ntiahome/dn/ [2002, February].

Peng ZR; Jan O. “Assessing Means Of Transit Information Delivery For Advanced Public Transportation Systems." Transportation Research Record 1666, pp. 92 100, 1999.

Robinson RK; Bakr MM; Thomson TL. "Study Of Commuter Choice Of Information Source To Improve Transit Information Systems." Transportation Research Record 735, pp. 20-23, 1979.

Transportation Research Board. "Transit Cooperative Research Program 45: Passenger Information Services: A Guidebook for Transit Systems.” 1999.

Transportation Research Board. "Transit Cooperative Research Program 92: Strategies for Improved Traveler Information.” 2003.

Transportation Research Board. "Transit Cooperative Research Program Synthesis 43: Effective Use of Transit Websites." 2002.

Transportation Research Board. "Transit Cooperative Research Program Synthesis 48: Real-Time Bus Arrival Information Systems.” 2003.

U.S. Department of Transportation. "Traveler Information Systems in Europe.” August 2003. 
Table 1 Types of information systems and their purposes

\begin{tabular}{|c|c|c|c|}
\hline & Pretrip & Transit Stop & In-Vehicle \\
\hline Purpose & $\begin{array}{l}\text { Route planning } \\
\text { General Operations } \\
\text { Fare information }\end{array}$ & $\begin{array}{l}\text { Anxiety relief } \\
\text { Route info } \\
\text { Real-time Arrival and } \\
\text { Delay Information }\end{array}$ & $\begin{array}{l}\text { Current location } \\
\text { Transfer information }\end{array}$ \\
\hline Static & Printed Schedules (Q7) & $\begin{array}{l}\text { Schedules (Q2 \& Q4) } \\
\text { Route Maps (Q2, Q4, \& Q9) } \\
\text { Transfer info } \\
\text { Station/Stop Identifier } \\
\text { Location Maps }\end{array}$ & $\begin{array}{l}\text { Route Map } \\
\text { System Map } \\
\text { Station/Stop Identifier }\end{array}$ \\
\hline Dynamic & $\begin{array}{l}\text { Kiosks (Q7) } \\
\text { Phone Systems } \\
\text { Websites (Q5 \& Q6) }\end{array}$ & $\begin{array}{l}\text { Kiosks (Q7) } \\
\text { Countdown (Q1 \& Q4) } \\
\text { Variable Message Board (Q9) } \\
\text { CCTV } \\
\text { Announcements (Q8) } \\
\text { Attendants }\end{array}$ & $\begin{array}{l}\text { Cellular/Wireless } \\
\text { Variable Message (Q3) } \\
\text { Board } \\
\text { Announcements } \\
\text { Dynamic Map } \\
\text { Driver }\end{array}$ \\
\hline $\begin{array}{l}\text { Most } \\
\text { Useful }\end{array}$ & Websites & $\begin{array}{l}\text { Variable Message Boards } \\
\text { CCTV } \\
\text { Kiosks }\end{array}$ & $\begin{array}{l}\text { Variable Message Boards } \\
\text { Announcements }\end{array}$ \\
\hline
\end{tabular}

\begin{tabular}{|l|l|l|}
\hline & Average & Standard Deviation \\
\hline Age (years) & 43.7 & 10.7 \\
\hline Commute to work (miles) & 14.5 & 15.0 \\
\hline Commute time (min) & 32.7 & 18.3 \\
\hline Household Size & 2.4 & 1.3 \\
\hline Household Income & $\$ 82,722$ & $\$ 40,783$ \\
\hline Gender & $30 \%$ Male & $60 \%$ Female \\
\hline
\end{tabular}


Table 3 Stated Preference Choice Sets

\begin{tabular}{|l|l|l|l|}
\hline $\begin{array}{l}\text { Choice 1 } \\
\text { Information }\end{array}$ & $\begin{array}{l}\text { Choice 2 } \\
\text { Information }\end{array}$ & $\begin{array}{l}\text { Average } \\
\text { Difference in } \\
\text { Value }\end{array}$ & $\begin{array}{l}\text { Standard } \\
\text { Deviation of } \\
\text { Difference } \\
\text { in Value }\end{array}$ \\
\hline $\begin{array}{l}\text { Q1: Real time Arrival } \\
\text { Information }\end{array}$ & No Information & $\$ 0.96$ & $\$ 1.06$ \\
\hline $\begin{array}{l}\text { Q2: Route map and } \\
\text { Schedule }\end{array}$ & Route Number & $\$ 1.00$ & $\$ 1.05$ \\
\hline $\begin{array}{l}\text { Q3: En-Route Real } \\
\text { Time Location } \\
\text { Information }\end{array}$ & No Information & $\$ 0.74$ & $\$ 1.02$ \\
\hline $\begin{array}{l}\text { Q4: Real-Time arrival } \\
\text { with route map and } \\
\text { schedule }\end{array}$ & $\begin{array}{l}\text { Route map and } \\
\text { Schedule }\end{array}$ & $\$ 0.85$ & $\$ 1.02$ \\
\hline $\begin{array}{l}\text { Q5: Online Trip } \\
\text { Planner }\end{array}$ & $\begin{array}{l}\text { Online Route } \\
\text { Information }\end{array}$ & $\$ 0.95$ & $\$ 1.02$ \\
\hline $\begin{array}{l}\text { Q6: Online Real- } \\
\text { Time Location } \\
\text { Information }\end{array}$ & $\begin{array}{l}\text { Online Route } \\
\text { Information }\end{array}$ & $\$ 0.95$ & $\$ 0.95$ \\
\hline $\begin{array}{l}\text { Q7: Information } \\
\text { Kiosk with Route } \\
\text { Planner }\end{array}$ & $\begin{array}{l}\text { Information Kiosk } \\
\text { with printed info }\end{array}$ & $\$ 0.63$ & $\$ 0.89$ \\
\hline $\begin{array}{l}\text { Q8: Delay } \\
\text { information and } \\
\text { Suggested } \\
\text { Alternatives }\end{array}$ & $\begin{array}{l}\text { Real-Time Arrival } \\
\text { Information }\end{array}$ & $\$ 0.79$ & $\$ 0.87$ \\
\hline Q9: System Map & Route Number & $\$ 0.61$ & \\
\hline
\end{tabular}


Table 4 OLS Regression Results

\begin{tabular}{|c|c|c|c|c|c|c|c|c|c|}
\hline & $\begin{array}{l}\text { Q1: Real } \\
\text { time Arrival } \\
\text { Information }\end{array}$ & $\begin{array}{l}\text { Q2: Route } \\
\text { map and } \\
\text { Schedule }\end{array}$ & $\begin{array}{l}\text { Q3: En-Route } \\
\text { Real Time } \\
\text { Location } \\
\text { Information }\end{array}$ & $\begin{array}{l}\text { Q4: Real- } \\
\text { Time arrival } \\
\text { with route } \\
\text { map and } \\
\text { schedule }\end{array}$ & $\begin{array}{l}\text { Q5: Online } \\
\text { Trip Planner }\end{array}$ & $\begin{array}{l}\text { Q6: Online } \\
\text { Real-Time } \\
\text { Location } \\
\text { Information } \\
\end{array}$ & $\begin{array}{l}\text { Q7: } \\
\text { Information } \\
\text { Kiosk with } \\
\text { Route } \\
\text { Planner } \\
\end{array}$ & $\begin{array}{l}\text { Q8: Delay } \\
\text { information } \\
\text { and } \\
\text { Suggested } \\
\text { Alternatives }\end{array}$ & $\begin{array}{l}\text { Q9: System } \\
\text { Map }\end{array}$ \\
\hline Constant & $\begin{array}{l}1.54 \text { *** } \\
(6.32)\end{array}$ & $\begin{array}{l}1.82^{* * *} \\
(6.94)\end{array}$ & $\begin{array}{l}1.39^{* * *} \\
(5.40)\end{array}$ & $\begin{array}{l}1.37^{* * *} \\
(5.42)\end{array}$ & $\begin{array}{l}1.62^{* * *} \\
(5.99)\end{array}$ & $\begin{array}{l}1.77^{* * *} \\
(7.43)\end{array}$ & $\begin{array}{l}1.39^{* * *} \\
(5.73)\end{array}$ & $\begin{array}{l}1.62^{* * *} \\
(6.52)\end{array}$ & $\begin{array}{l}1.35^{* * *} \\
(5.97)\end{array}$ \\
\hline Age $20-30$ & $\begin{array}{l}0.38 \\
(1.30) \\
\end{array}$ & $\begin{array}{l}0.34 \\
(1.09) \\
\end{array}$ & $\begin{array}{l}0.05 \\
(0.15)\end{array}$ & $\begin{array}{l}0.59 * \\
(1.95)\end{array}$ & $\begin{array}{l}0.59 * \\
(1.87)\end{array}$ & $\begin{array}{l}0.57^{* *} \\
(2.04)\end{array}$ & $\begin{array}{l}0.18 \\
(0.64)\end{array}$ & $\begin{array}{l}0.48^{*} \\
(1.67)\end{array}$ & $\begin{array}{l}0.48^{*} \\
(1.81) \\
\end{array}$ \\
\hline Gender & $\begin{array}{l}-0.34 \\
(-1.58)\end{array}$ & $\begin{array}{l}-0.54^{\star *} \\
(-2.33)\end{array}$ & $\begin{array}{l}-0.16 \\
(-0.69)\end{array}$ & $\begin{array}{l}-0.29 \\
(-1.29)\end{array}$ & $\begin{array}{l}-0.49^{\star *} \\
(-2.07)\end{array}$ & $\begin{array}{l}-0.57^{* * *} \\
(-2.71)\end{array}$ & $\begin{array}{l}-0.25 \\
(-1.19)\end{array}$ & $\begin{array}{l}-0.29 \\
(-1.34)\end{array}$ & $\begin{array}{l}-0.13 \\
(-0.67)\end{array}$ \\
\hline \#Vehicles & $\begin{array}{l}0.30^{\star \star *} \\
(2.85)\end{array}$ & $\begin{array}{l}0.21^{*} \\
(1.85)\end{array}$ & $\begin{array}{l}0.26^{\star *} \\
(2.34)\end{array}$ & $\begin{array}{l}0.28 * * \\
(2.51)\end{array}$ & $\begin{array}{l}0.20^{*} \\
(1.71)\end{array}$ & $\begin{array}{l}0.19^{*} \\
(1.85)\end{array}$ & $\begin{array}{l}0.18^{*} \\
(1.72)\end{array}$ & $\begin{array}{l}0.18 \\
(1.66)\end{array}$ & $\begin{array}{l}0.24^{* *} \\
(2.41)\end{array}$ \\
\hline $\begin{array}{l}\text { High } \\
\text { Income }\end{array}$ & $\begin{array}{l}0.48^{\star} \\
(1.86)\end{array}$ & $\begin{array}{l}0.49^{*} \\
(1.79)\end{array}$ & $\begin{array}{l}0.03 \\
(0.12)\end{array}$ & $\begin{array}{l}0.05 \\
(0.17)\end{array}$ & $\begin{array}{l}0.20 \\
(0.68)\end{array}$ & $\begin{array}{l}0.28 \\
(1.09)\end{array}$ & $\begin{array}{l}0.28 \\
(1.09)\end{array}$ & $\begin{array}{l}-0.09 \\
(-0.35)\end{array}$ & $\begin{array}{l}-0.03 \\
(-0.12)\end{array}$ \\
\hline $\begin{array}{l}\text { Recent } \\
\text { Bus }\end{array}$ & $\begin{array}{l}-0.50^{* *} \\
(-2.29)\end{array}$ & $\begin{array}{l}-0.49 * * \\
(-2.07)\end{array}$ & $\begin{array}{l}-0.32 \\
(-1.38)\end{array}$ & $\begin{array}{l}-0.15 \\
(-0.67)\end{array}$ & $\begin{array}{l}-0.01 \\
(-0.03)\end{array}$ & $\begin{array}{l}-0.42^{*} \\
(-1.94)\end{array}$ & $\begin{array}{l}-0.25 \\
(-1.14)\end{array}$ & $\begin{array}{l}-0.28 \\
(-1.25)\end{array}$ & $\begin{array}{l}-0.37^{*} \\
(-1.83)\end{array}$ \\
\hline Work Dist & $\begin{array}{l}-0.61^{* *} \\
(-2.21)\end{array}$ & $\begin{array}{l}-0.48 \\
(-1.62) \\
\end{array}$ & $\begin{array}{l}-0.42 \\
(-1.45) \\
\end{array}$ & $\begin{array}{l}-0.38 \\
(-1.34) \\
\end{array}$ & $\begin{array}{l}-0.04 \\
(-0.14) \\
\end{array}$ & $\begin{array}{l}-0.23 \\
(-0.84)\end{array}$ & $\begin{array}{l}-0.20 \\
(-0.75)\end{array}$ & $\begin{array}{l}-0.45 \\
(-1.60) \\
\end{array}$ & $\begin{array}{l}-0.60^{\star *} \\
(-2.36)\end{array}$ \\
\hline R-Sq(adj) & $24.5 \%$ & $19.5 \%$ & $5.7 \%$ & $11.1 \%$ & $9.6 \%$ & $20.0 \%$ & $6.2 \%$ & $7.6 \%$ & $13.4 \%$ \\
\hline
\end{tabular}

Note: (t-statistic) in parenthesis

$*=0.1$ significance, $* *=0.05$ significance, $* * *=0.01$ significance 
Figure 1 Screen shots from stated preference survey

Q1

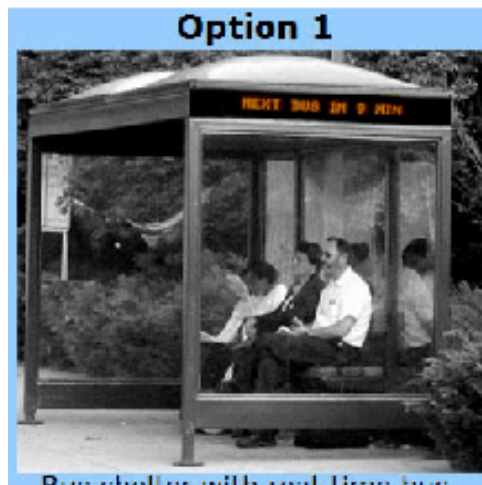

Bus shelter wilh real Lime uus arrival in onmation
Option 2

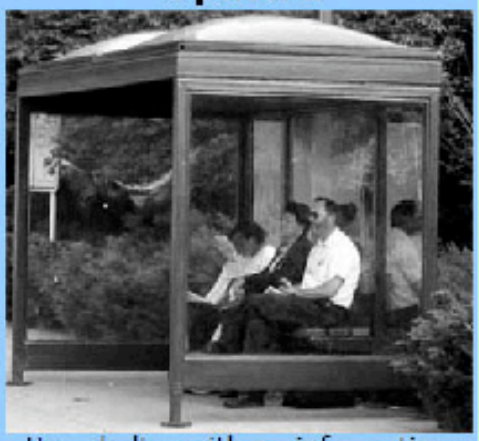

Bus shelter with no information

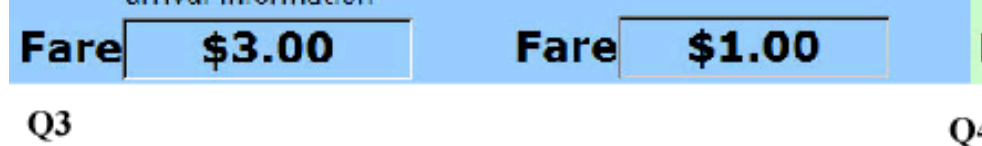

Q2

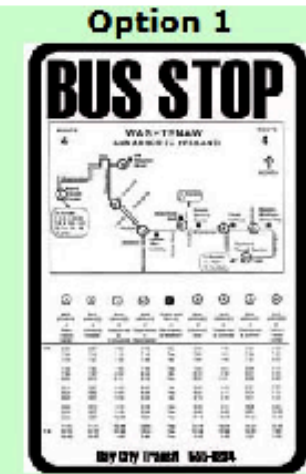

Buss slon wilh roule isnel sctiedule informalion
Q4

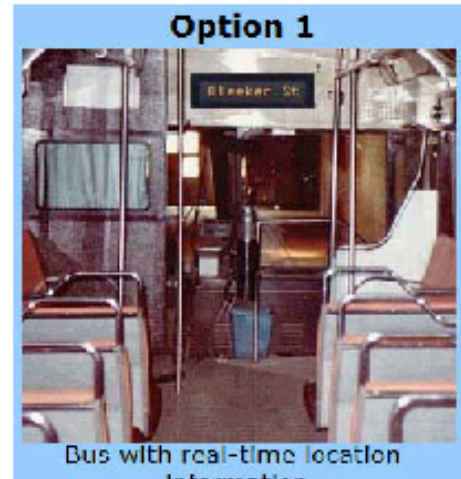

Intormation

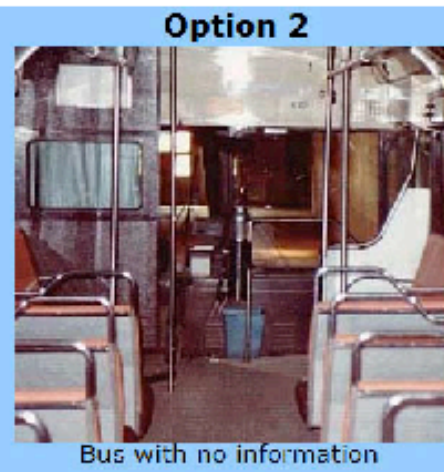

Fare

$\mathbf{\$ 3 . 0 0}$

Fare $\$ \mathbf{\$ 1 . 0 0}$
Option 2

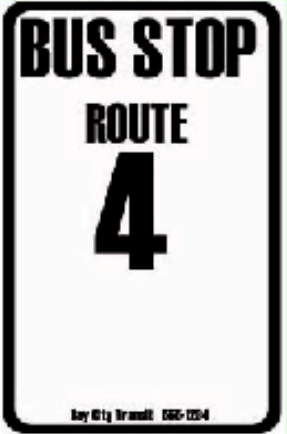

Hus slare wilt no inforerral

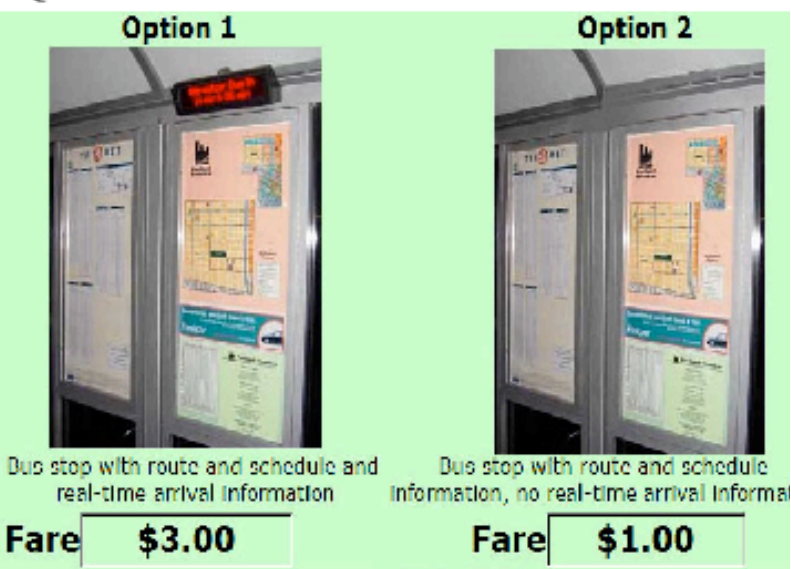

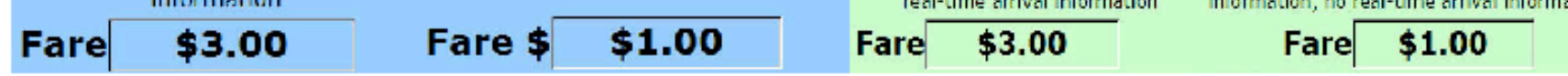

Q5

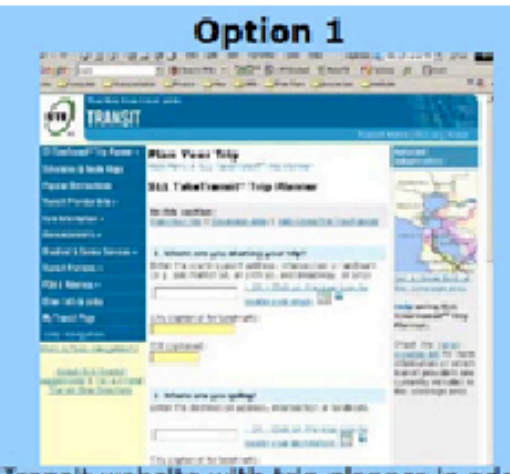

Transit website with trip planner in addition Transit website with indlvidual schedule and to individual schedule and route information

Fare $\$ 3.00$ route information but no trip planner

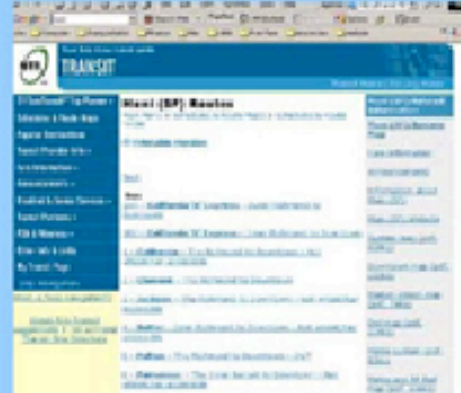

Fare $\$ 1.00$ 
Figure 2 Screen shots from stated preference survey

Q6

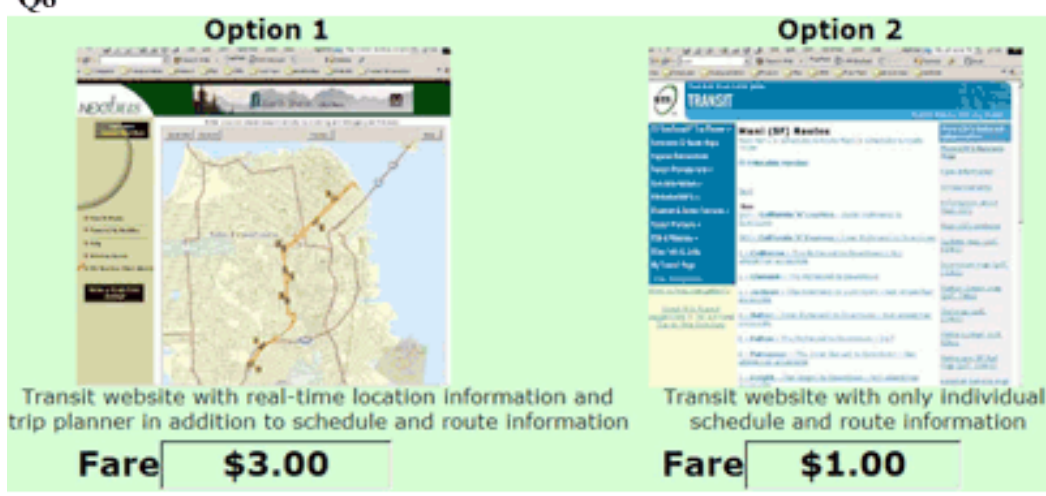

Q7

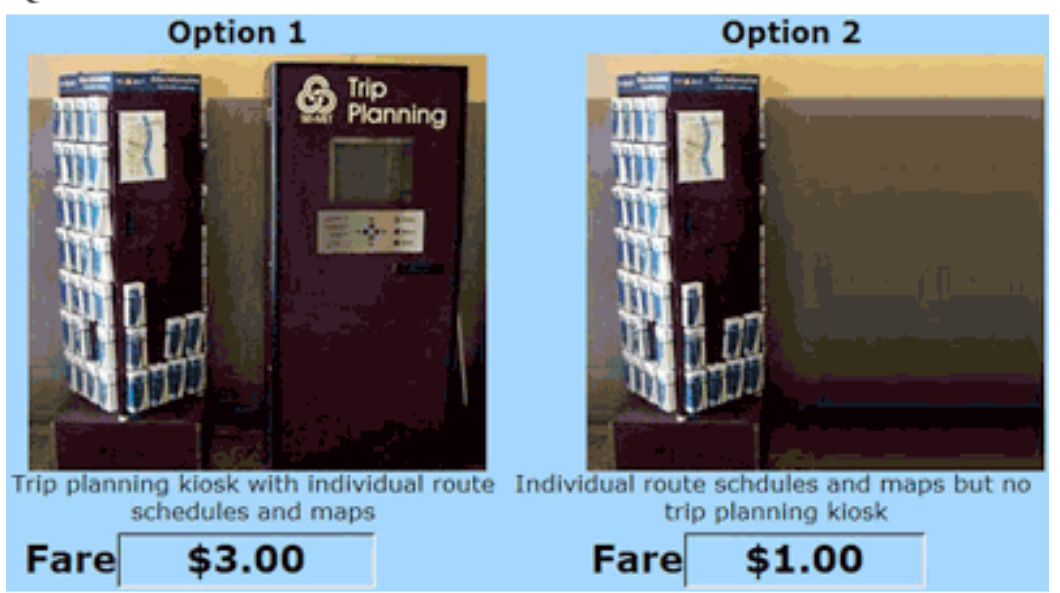

Q8
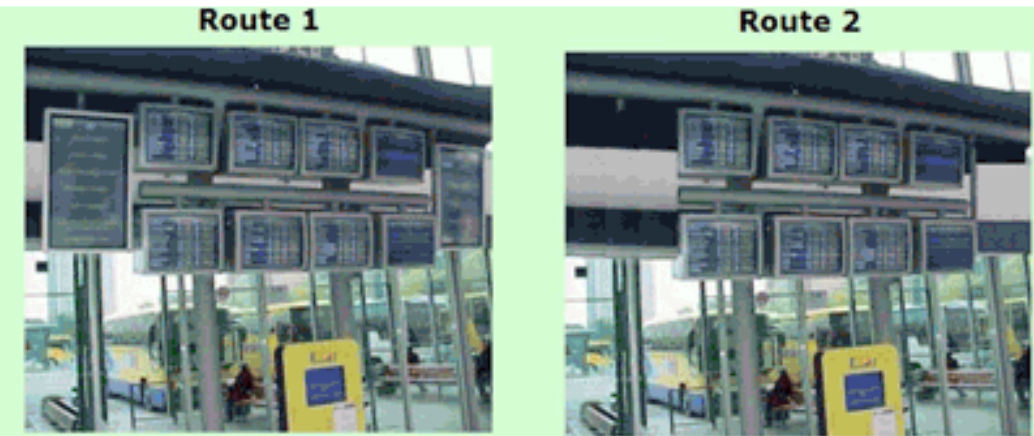

Transit Center with real-time arrival and delay Transit Center with real-time arrival information with suggested alternate routes information but no extra information
Fare
$\$ \mathbf{3 . 0 0}$
Fare $\$ 1.00$ 
Figure 3 Screen shots from stated preference survey

Q9

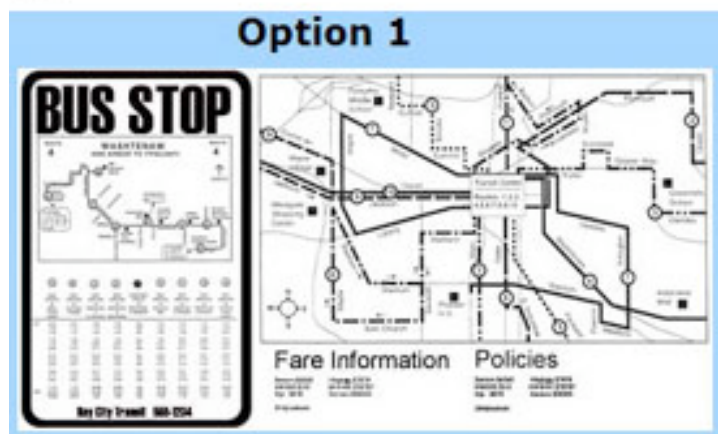

Option 2

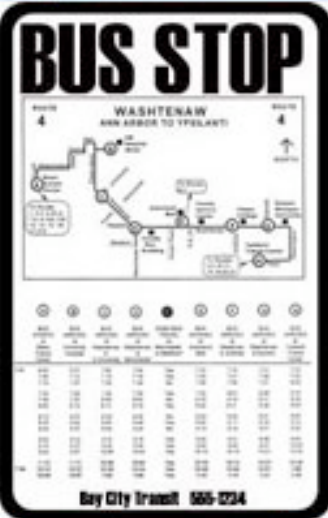

Bus stop with system map, fare information, route map, and schedule
Fare
$\$ \mathbf{3 . 0 0}$
Fare
$\$ 1.00$ 